\title{
MOBILE LEARNING TO IMPROVE WRITING IN ESL TEACHING
}

\author{
Heydy Selene Robles Noriega \\ (hrobles@uninorte.edu.co) \\ Universidad del Norte \\ Barranquilla, Atlantico, Colombia
}

\begin{abstract}
This article reports on the results of a study concerning the type of texts and their features produced by a student after using mobile technology as a support to improve the development of the students' writing skills in a second language. The Functional Systemic Linguistic (FSL), Genre Pedagogical Approach (GPA), and mobile learning concepts were employed as theoretical framework. The participant of the research was a freshman student that belongs to an English narrative course in a private university of the Caribbean region, Universidad Del Norte in Barranquilla, Colombia. This case study analyzed the student's writing during a period of eight-week course, which was then complemented with an interview conducted by the researcher. The results reveal that genre approach can be implemented with mobile technology to increase students' writing ability.
\end{abstract}

Keywords: genre pedagogy, second language, writing skills, mobile learning

DOI: http://dx.doi.org/10.15639/teflinjournal.v27i1/182-202

The gradual inclusion of new information and communication technologies in educational contexts has not been a new or a unique element. Hanson-Smith (2000) states that discussion on the use of technology (the use of cassettes, tape recorders, etc.) in classrooms had already started in the 1960s; at that time technology was mentioned as an instrument to facilitate the teaching of second language. Currently, technology in classroom has included the implementation of mobile devices to support the teaching and learning processes (Naish, 2005; O’Connell \& Smith, 2007). 


\section{Mobile Learning}

Teaching languages especially foreign languages assisted by computers or CALL (Computer-Assisted Language Learning) and by mobile device or MALL (Mobile-Assisted Language Learning) is an example of how new communication technologies can be used to serve the learning objectives (Stockwell, 2010). Within this approach, mobile learning refers to the acquisition of knowledge through mobile devices. This means that learning takes place anywhere and any time. Its implementation apparently serves not as a new way to learn languages but rather as a complement to specific learning activities in the educative context (Venkatesh, Nargundkar, Sayed, \& Shahaida, 2006; Martin $\&$ Ertzberger, 2013). This was done because not all learning contents can be transmitted through mobile technology (Taylor, 2007). Contents used in mobile learning must be short and light so they allow for feedback and periodical revision due to the mobility implied (Looi, et al., 2010).

One of the options for mobile learning includes "Podcasts" (audio or video files transmitted through Internet) which are media to show contents and are considered useful to facilitate learning English as a foreign language (McCarthy, 2005) because they allow students to practice their skills outside the classroom. The great benefits of podcasts include their easy download, not only on PCs but also on any mobile device, which then leads to increasing mobility of their users.

\section{The Functional-Systemic Approach}

Functional Systemic Linguistics (FSL) conceives language as a resource to build, elaborate and explain meanings immersed in the social and cultural context (Eggins, 2004). Its main objective is to know how language works in particular settings and cultural background that allows an understanding of what takes place in the context (Ghio \& Fernández, 2005).

A text genre is determined by the culture in which the text is used. For this reason, different cultures reach their objectives through language in different ways (Derewianka, 1990). This is to say that people belonging to the same culture share social objectives using language and taking into account the topic discussed both in written or spoken contexts. Social contexts are molded by people who use the language (Colombi, 2009).

On the other hand, Schleppegrell (2006) defines FSL as a theory of language which offers tools to identify linguistic characteristics which are relevant 
in the construction of different kinds of texts. This way, using LSF, students learn to be conscious of three language functions: ideational (language is used to represent experiences), interpersonal (language is used to interact with others), and textual (language is used to construct coherent discourses (Lirola, 2006).

\section{Genre Pedagogical Approach (GPA)}

Former pedagogies to approach the study of this ability emphasized on the form of the text. This is to say that the development of writing skills in a foreign language was centered in the ability to construct coherent grammatical structures, especially in the formal aspects of the text, leaving apart the relation existing between the context and the written text. Additionally, the role of the teacher consisted of presenting students model texts to simply be adapted (Tribble, 1996; Lirola \& Cuevas, 2008). At the same time, students were not taught the common linguistic characteristics of a specific genre, which allow them to predict their context (Lirola \& Cuevas, 2008).

In contrast with the former pedagogy, the pedagogic approach based on genre (types of texts) which appeared in the $80 \mathrm{~s}$, has become a central concept in the studies of teaching writing in a second language (Tardy, 2011). Several scholars (Martin, 1985; Christie, 1987; Martin 1992; Feez, 1998) within the context of Functional Systemic Linguistics (FSL) initially developed this approach in Australia.

In the genre approach, language is a dynamic and open system where genres are used as a starting point to model, deconstruct and understand language (Rose, 2008). For many language teachers, this pedagogical approach has been favorable because it offers valuable resources to help all kinds of students to produce efficient texts (Hyland, 2007; Tangpermpoon, 2008; Lirola, 2006).

The GPA is used to design the content of the podcasts in this study because the narrative course in which the research is carried out is taught under the Genre Pedagogical Approach.

\section{Text Qualities}

Other characteristics of texts were analyzed in this study, such as coherence. According to Halliday and Hassan (1976), coherence is defined as the meaning relations existing within a text. Likewise, Nunan (1999) describes it as 
words or phrases, which allow the writer to establish links that helps to put sentences together.

The genres used in this study were personal recounts, autobiography and short story. Firstly, personal recounts are texts that reconstruct a past experience containing a series of events, and its aim is to retell them with the purpose of entertaining or informing (Martin \& Rose, 2008; Derewianka, 1990; Feez, 2002). The genre structure contains a first stage called orientation where basic information for contextualization for the reader or listener is provided. Then, a series of events are described, and the last stage called reorientation is a personal comment to evaluate the experience.

Secondly, autobiographies are texts used to tell significant events in the life of the writer. The structure usually explicitly identifies time periods of life (When I lived with X). According to Rose (2008), the genre structure presents an orientation and a series of significant events in the participant's life. Lastly, short stories are texts that require the following structure: an orientation, a complication and a resolution (Feez, 2002; Martin \& Rose, 2008). Its purpose is for entertainment or to deal with an issue. The particular language characteristics of this kind of text are: a series of clauses in the past tense, linked with time markers such as: yesterday, last week, etc.

This study is focused on how the genre pedagogy through mobile learning improves English text qualities of a Colombian student in a private university. These following two research questions guide the study:

1. What type of texts does the participant produce better after the implementation of genre pedagogy with podcasts?

2. What are the patterns of the texts elaborated by the participant after the use of genre pedagogy with podcasts?

\section{METHOD}

This research was developed with the case study modality, as defined by Sampieri and Mendoza (2008, p. 162): "a research, that through quantitative and qualitative or mixed processes analyzes an integral unit in depth to respond to the problem stated, to prove a hypothesis and to develop theory". Subjects were selected taking into account their availability to participate in the research experience.

This case study follows Sampieri and Mendoza's (2008) guidelines for the study of mixed and sequential cases implemented in one single subject. In other 
words, it examines one single human unit with qualitative and quantitative methods implemented in a sequence. The advantages of a case study make it a conventional tool for using it in quantitative and qualitative research, as they offer deeper and richer information (Shaughnessy, Zechmeister, \& Zechmeister, 2007).

The subject of this research was an International Relation student from Universidad del Norte, Colombia. The 19-year-old freshman student attended a narrative class with the researcher, and volunteered for the study. Her English level according to the Common European Framework was B1. This process was developed in an eight-week period.

The case study was developed from a semi-structured interview, which aimed at eliciting several aspects of student's experience with podcasts. This includes the way the student used the podcasts and how it influences her motivation and attention in class. Some of the questions respond to topics already studied in her narrative class, which have helped create a framework to understand the study object (see Appendix 1).

First of all, the participant produced an initial text of each type (personal recounts, autobiography and short stories) before receiving the explicit instruction (in class) of the aim of each stage of the types of texts (the genre structure) and the linguistic characteristics of the different types of texts with the purpose of identifying the state of her writing skills. After the first production, a mobile device with a podcast about the type of text studied in class is given to the student. The podcasts previously designed by the teacher contained the structure of the types of narrative texts with graphic organizers.

The participant took the mobile device home for two weeks. In the third week, prior to instutional tests, the participant rewrote the type of text already checked to identify the state of the writing skills after using the podcast. The intention was to distinguish which aspects (steps of the genre structure, text unit, graphology and spelling) had improved.

\section{FINDINGS AND DISCUSSION}

\section{Findings}

The written production of the participant was analyzed in relation to linguistic patterns and genre characteristics presented before and after checking the podcasts. The analysis of the texts (personal recounts, autobiography and 
short stories) was based on four aspects: the genre structure, the text unit, and the graphology aspects. The first one, the genre structure, refers to the organization of steps that a genre must complete to achieve its aim (Rose, 2008). The text unit refers to cohesion; the grammatical aspects refer to sentence construction in declarative ways and the group of processes (verbs) and, finally to spelling and punctuation (Feez, 2002). When writing personal recount text, the participant was asked to narrate the events developed during the weekend. In autobiography she wrote about the most significant events in her life. Finally, in short story, she was asked to rewrite a brief story after reading it. In this case the short story was "The window", an anonymous short story with a moral.

\section{Analysis of Personal Recount Text}

Figure 1 and 2 describe the comparison of the student's writing before and after the implementation of podcasts in mobile devices. The student took approximately 25 minutes writing the initial personal recount. While in the second production, the student took less time. The podcast showed a fish graphic organizer with the structure of a personal recount.

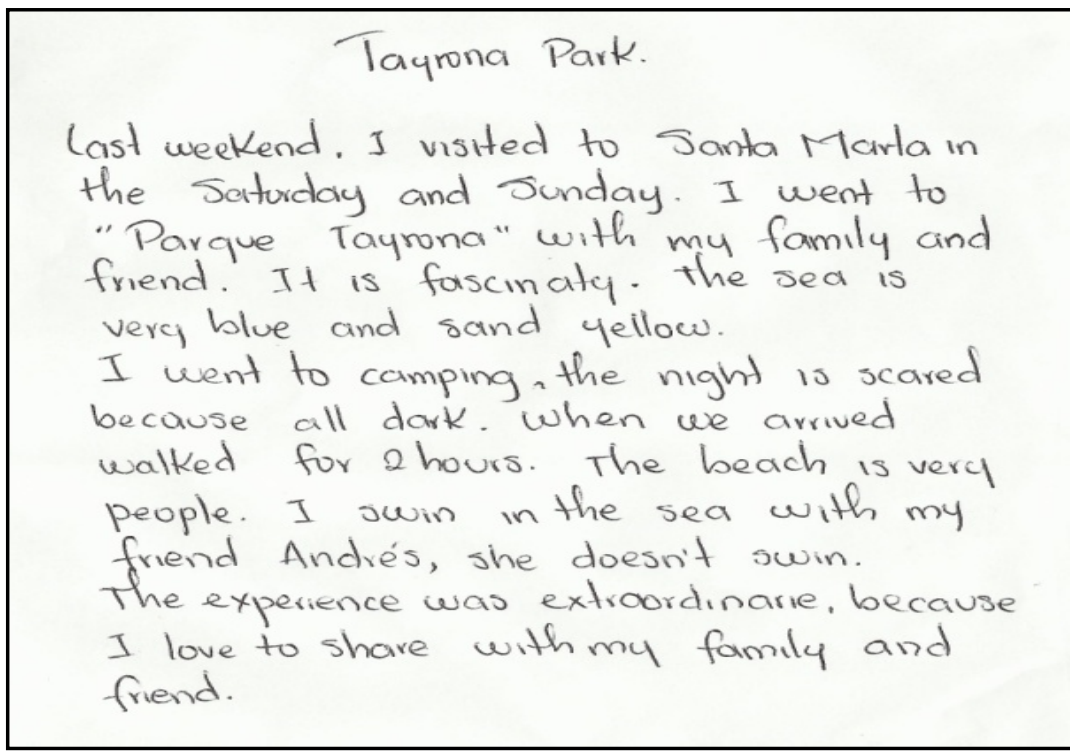

Figure 1: Subject's Initial Recount 


\section{Tayrona Park}

Last week, I went to Santa Marta with my friend André. Juan Gabriel and Maria. We were very excited to this city. First, we went to Tayrona Park with my formily and friends. We walked around the "Baroco" beaches and we swon on the sea.

After we ate seafood, coconut rice and "patacones". Then we sumbathe and I listened to music. Next we went to camping to night. I was scared, because everything was dark. Finally, we went back at home. Tayrond park beaches are beautiful! It was a funny and nice experience.

Figure 2: Subject's Final Recount

Having compared both texts, it can be observed that the quality of the second text was better, and the student seemed to have developed in several aspects. Table 1 lists a short summary of the main aspects in which the quality of both products differs quite significantly. 
Table 1. Difference in Recounting: Initial and Final

\begin{tabular}{|c|c|}
\hline INITIAL & FINAL \\
\hline \multicolumn{2}{|c|}{ Genre Structure } \\
\hline $\begin{array}{l}\text { The text hardly shows the fundamental } \\
\text { parts of recounting. There are no defined } \\
\text { separations between the sequence of } \\
\text { events and the orientation. There is no } \\
\text { description of the trip events, although } \\
\text { there is a reorientation which fulfills the } \\
\text { objective of evaluating the travelling ex- } \\
\text { perience. }\end{array}$ & $\begin{array}{l}\text { The text shows clearly the three stages of } \\
\text { recounting: orientation, events and reori- } \\
\text { entation. In the reorientation, she adds an- } \\
\text { other participant, which she had not in- } \\
\text { cluded in her first recount. She also shows } \\
\text { a clearer and more elaborate language } \\
\text { when compared with the first text. For ex- } \\
\text { ample, she changes the action of visiting } \\
\text { for: I went to Santa Marta. }\end{array}$ \\
\hline \multicolumn{2}{|c|}{ Text Unit- Cohesion } \\
\hline $\begin{array}{l}\text { There is a weak use of logic connectors } \\
\text { and referents that allow a better under- } \\
\text { standing of the context. Likewise, the text } \\
\text { lacks the use of appropriate pronouns to } \\
\text { refer to what has been previously men- } \\
\text { tioned. There is no lexical variety. That is, } \\
\text { she needs more terms for every sub-topic. } \\
\text { For example in line } 3 \text {, when she mentions } \\
\text { the place (Parque Tayrona, she tries to de- } \\
\text { scribe it. }\end{array}$ & $\begin{array}{l}\text { It includes some of the sequence connect- } \\
\text { ors corresponding to narrative texts, such } \\
\text { as: first, after, finally, which allow a better } \\
\text { text organization and the establishment of } \\
\text { a logical order of ideas. } \\
\text { The text shows an improvement in lexical } \\
\text { cohesion. For example, at the end of the } \\
\text { text she includes words to describe the } \\
\text { experience: It was a funny and nice expe- } \\
\text { rience. }\end{array}$ \\
\hline
\end{tabular}

Spelling and Punctuation

There are spelling mistakes, such as: fascinaty and extraordinarie. It seems to be a negative transfer from French to English.

Absence of spelling mistakes shows improvement.

\section{Grammatical Aspects}

Most actions are in the past tense, such as visited, went, and arrived. Nevertheless, there are state actions in the present tense that should be in the past form, such as: is.

There is a mixture of present and past:
The text shows appropriate language characteristics for recount text. This means that all the actions that happened in the past are expressed in the past tense. Nevertheless, there is an action which is still in the present tense: we sunbathe. 
She doesn't swam.

There is transfer from the mother tongue:

the appropriate order of adjectives: sand

yellow. There are also inadequate gram-

mar constructions: The beach is people.

The night is scared.

\section{Analysis of Autobiography Text}

Figures 3 and 4 illustrate the autobiographies recounted by the participant before and after the experience of the implementation of podcasts.

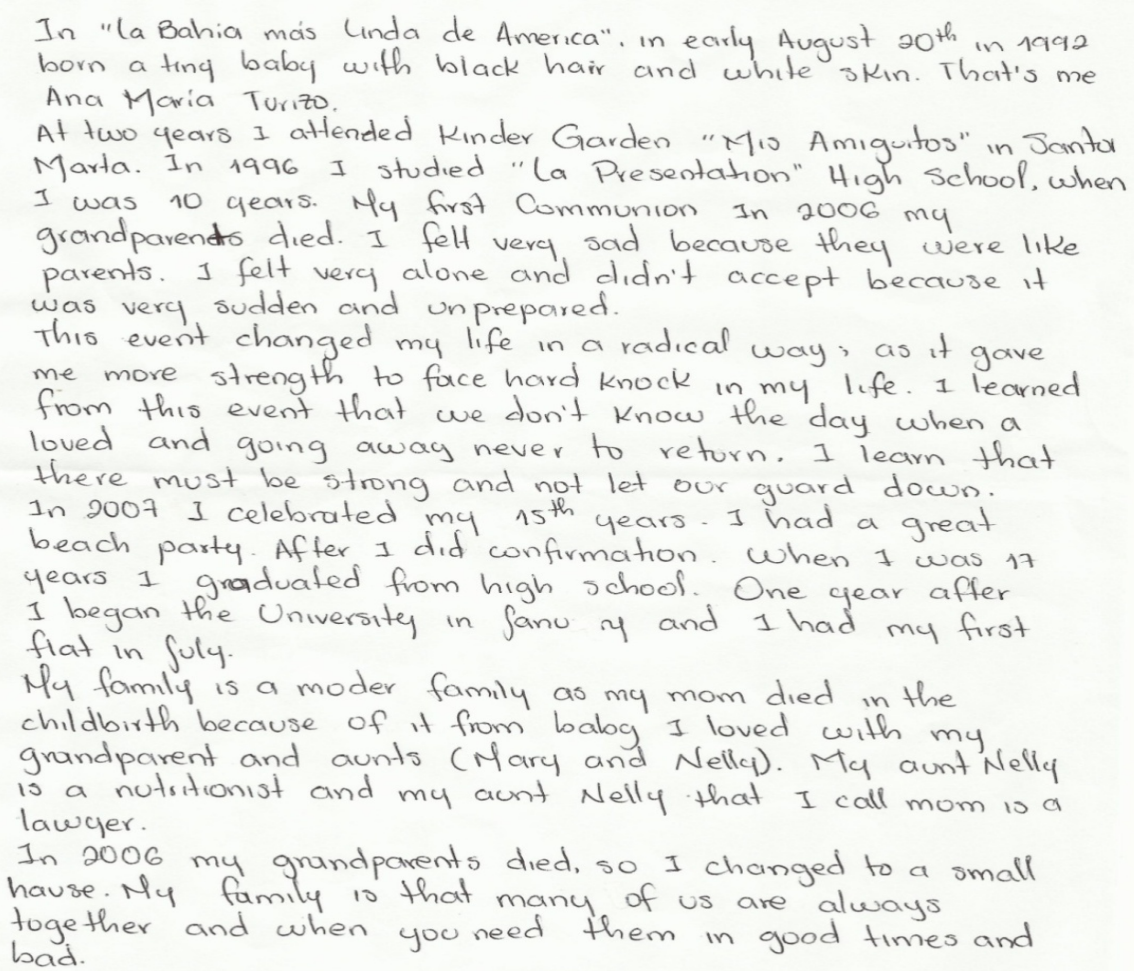

Figure 3: Subject's Initial Autobiography 
In the most beautiful bay of America. Santa Marta. In nearly August $20^{\text {th }}$ in 1992 a tiny baby born with black hair and white skin; that's me Ana Maria Turizo.

1 'm responsible, very happy. polite, sociable, intelligent and funy.

When 1 was 2 years 1 attended "Mis Amigutos" Kinder garden. In 1996 I studied "La presentation" Slakool. When I was 10 gears 1 received the first communion.

In 2006 my grandparents died. I felt very sad because they were like my parents. I felt very alone and I didn't accept because I was very very sudden and unexpected. this event changed my life in a radical way. I gave more strength to me forwand. I learned from this event we must we the time pussible with loved ones.

In 2007 I celebrated my $15^{\text {th }}$ years in a great beach partey. 1 year affer that I did my confirmation. In 2009 I graduated from high school. When I was 17 years I began the University in January and I had my first flat in july.

My fumily is a modern fumily because my mom died 2 years after I was born as 1 went to live my grandparents and my aunts (Mary and Nelly).

My aunts Mary is a nutritionist. My aunt Nelly that call me mom is a lawyer.

I have a big family we usually. together a when good time, and bad.

Hy short term plans are I study English and French in Canada for 9 months. Affer 1 went to Brazil 1 job in humanitarian onganization for 5 months, because 1 have a professional practice.

ify professional dream is a excellent internationalist and I hope work in NGO's.

My personal future is still uncertain. I would be have more children and get married.

Figure 4: Subject's Final Autobiography 
The following Table 2 shows in detail the analysis of the autobiography of the participant before and after the use of podcasts designed by the teacher.

\section{Table 2. Differences in the Autobiography Production}

\begin{tabular}{|c|c|}
\hline INITIAL & FINAL \\
\hline \multicolumn{2}{|c|}{ Genre Structure } \\
\hline $\begin{array}{l}\text { The text shows orientation and events re- } \\
\text { count but it does not have a reorientation. In } \\
\text { the orientation we could observe how the } \\
\text { participant identifies herself and mentions } \\
\text { her birth date and place. Then, she mentions } \\
\text { a series of chronological events about her } \\
\text { life. Nevertheless, there is a short non-logical } \\
\text { description of her family at the end of the } \\
\text { events. }\end{array}$ & $\begin{array}{l}\text { The text describes the stages of the autobiog- } \\
\text { raphy: an orientation where the participant } \\
\text { describes details about her personality, a se- } \\
\text { quence of events, and a reorientation where } \\
\text { she expresses her future plans. }\end{array}$ \\
\hline
\end{tabular}

\section{Text Unit-Cohesion}

Absence of logical connectors or their inappropriate use is observed. These make events appear in a compact manner without demarcation, which affects logic and sense of narration.

An example of the incorrect use of connectors is in line 15: I had a great beach party. After I did a confirmation.

One good example is in paragraph 3: one year after where she presents an appropriate use.

There is transfer from L1 to L2: It gave me more strength to face hard knock in my life.
Although the text has few connectors in relation to the autobiography genre, there is more clarity of the ideas. Nevertheless some connectors are used inappropriately. For example, in line 20: My family is a modern family because my mom died 2 years after I was born.

She uses terms related to her future plans in the reorientation stage: My short term plans, my professional dreams, and my personal future.

The text shows improvement in the construction of sentences with simple arguments: I learned from this event that we must use the time possible with loved ones.

Spelling and Punctuation problems.

The text does not show spelling problems. It is similar to the first one. 


\section{Grammatical Aspects}

\begin{tabular}{ll}
\hline There is confusion of process verbs: I would & There is more coherence in the ideas even \\
be have more children. & though there is negative transfer from L1 to \\
There is also confusion with verbal forms. & L2 (Spanish). For example, \\
$\begin{array}{ll}\text { For example, she uses future expressions, but } & \text { in line 6: When I was 2 years I attended.... } \\
\text { the actions are in the past. } & \text { and line 8:...I received the first communion. }\end{array}$
\end{tabular}

\section{Analysis of Short Story Text}

The following Figures 5 and 6 show in detail the short story genre production before and after the experience of podcasts implementation.

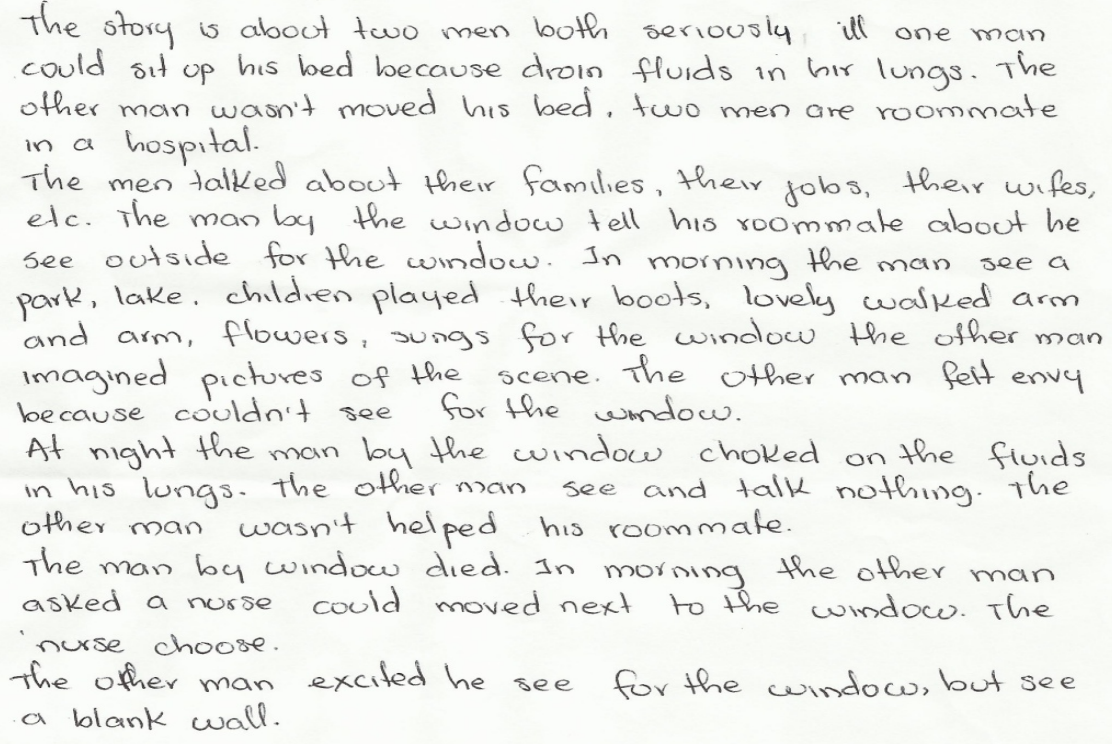

Figure 5: Subject's Initial Short story 


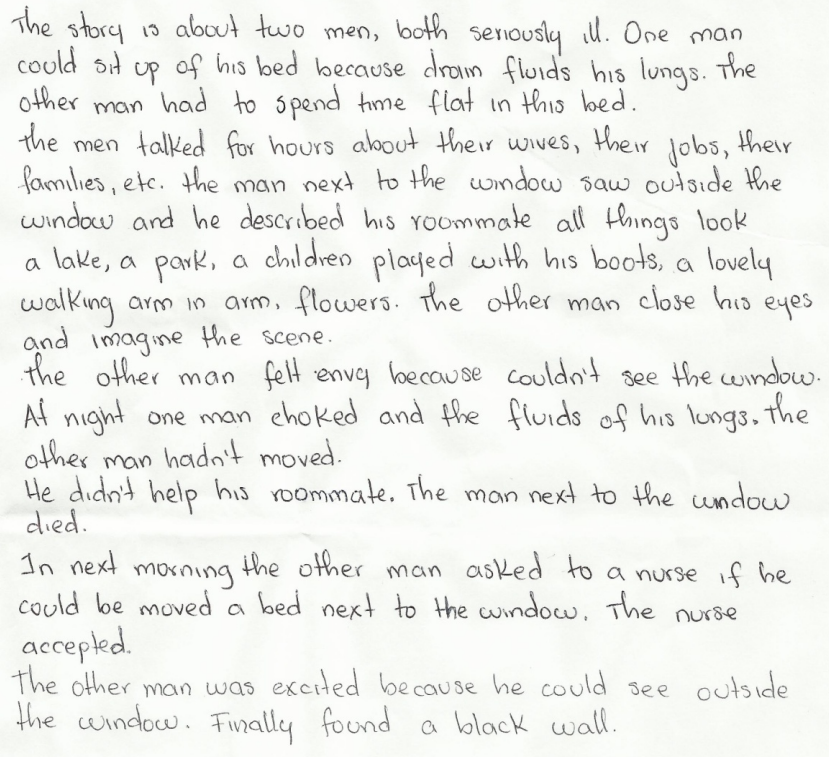

Figure 6: Subject's Final Short story

The following table summarizes the differences observed in the short story text.

Table 3. Differences in the Initial and Final Short Story Production

\begin{tabular}{c}
\hline INITIAL \\
\hline Genre Structure \\
\hline
\end{tabular}

The text has an orientation. However, the sequence of events is not clear and therefore, the knot stage is not identified. It also does not have a resolution stage.
The text shows orientation, and the events in the different stages of the story have details. It is clear also that she has tried to finish with a resolution when she includes the connector finally. Nevertheless, she lacks precision. The knot dilutes in the events and it is hard to identify it.

It is worth mentioning that the participant uses almost the same terms as in the first production. 


\section{Text Unit- Cohesion}

The text needs logical connectors to make the story flow smoothly and help readers understand the story events.

There are pronoun references, but in some occasions, they are inappropriate. For example, in line 2: one man could sit up of his bed because drain fluids in her lungs.
The text has very few connectors. It only mentions two: in next morning and Finally. Moreover, they do not help to connect ideas and make them coherent.

The text only shows reference to the personal pronoun she and the possessive adjectives his and their. Other than that, lack of cohesion still remains.

\section{Spelling and Punctuation}

There is lack of appropriate punctuations to help understand the events better.

There are problems with the use of capital letters.

Very few spelling mistakes, e.g.: Their wifes

\section{Grammatical Aspects}

The text shows sentences lacking processes and therefore understanding is difficult. For example in line 2: ... because drain fluids his lungs. The other man wasn't moved his bed.

There is negative transfer from L1 (Spanish) to L2, for example in line 9 and 18: for the window.

Another case is the omission of pronoun he; see line 18:...but see a black wall.

It contains unclear sentences. For example:...he described his roommate all things look a lake, a park, , a lovely walking arm in arm.
There is an improvement in the use of capital letters.

No spelling mistakes are observed.
There is improvement concerning the verbal tenses used although there are still actions in the present simple. For example, in line 8:...the other man close his eyes and imagine the scene

There is also a better use of the auxiliary verbs as can be seen in line 13: She didn't help his roommate.

The text shows some connectors, but they are not used properly. 
The text describes some past events using verbs in the present tense. For example, in line 7:

In the morning the man see a park...

On some occasions, she omits the main action of the sentence. See in line 18: The other man excited she

see...

\section{Analysis of the Interview}

The interview dealt with three aspects: (1) learning results which concern the changes perceived by the subject in her abilities to develop written texts of different kinds of narrative genres, (2) the role of podcast in the learning process, and (3) affective factors such as attention and motivation related to the use of technological tools for improving the production of written texts.

\section{Learning Results}

The first question concerns the changes observed by participant when writing the three types of texts. The student mentioned that she felt most satisfied with the change in the register of her written production.

After the experience with the podcasts, the texts not only showed appropriate structure as suggested by the narrative course, but also, according to the participant, were more coherent.

During the interview, the participant expressed that aspects such as grammar, coherence and vocabulary improved in her writing as a product of the intervention; this was reflected in a less frequent use of online translators and the construction of more clear and concise sentences. It is important to highlight that the participant acknowledged that autobiographies were the easiest texts to write. The participant stated that referring to a personal and more vivid past experience made it more possible to organize the events chronologically.

\section{Podcasts and the Learning Process}

Concerning the question about the use of podcasts for learning, the student reported that she had already used web tools. Nevertheless, she added that she 
used the tools mostly for searching information, reproducing music and videos and others. It is worth mentioning that the participant had never thought about the potential use of mobile devices to support her learning process. The student revealed that they undoubtedly had played a crucial role in learning about the structure of types of texts.

During the study sessions, the element the participant considered most important were the summaries she wrote of each topic and of each production. The participant also used the podcasts to guide and revise the production of her writings. Among other aspects, she also described that the mobile device allowed her to access other types of resources, such as websites which gave her support for the development of activities in different topics.

\section{Attention and Motivation in Class}

The participant was asked about how the use of mobile devices affects her motivation to attend classes and the attention devoted to them. She acknowledged that the digital materials summarized great part of the class content and therefore, face-to-face teaching was not essential to understand the topics.

"You did not really have to go to class to understand a topic because nowadays there is so much technology that you do not have to be there to understand because there (on the video) was everything".

Regarding the attention, she expressed that she was more attentive, especially during the regular evaluations carried out in the narrative course.

"Obviously attention increased as it was the easiest way to understand the topics".

\section{Discussion}

Regarding the first question of this study, personal recounts seem to be the type of texts that are better produced. One of the reasons for this may be the short time taken to retell recent experiences and also, it is one of the most frequent genres used in teaching writing to students in their mother tongue (Chen, 2008). Additionally, recounting is considered one of the simplest narrative text types since events are presented one after the other in their order of occurrence (Feez, 2002). This finding coincides with Chaisiri's study (2010) that the im- 
plementation of genre-based approach may produce promising improvements in students' writing.

On the other hand, concerning the second aspect related to linguistic patterns, there is no significant change in the before and after the written productions, except in the appropriate use of the past tenses. It also seems that irregular verbs were among items that the participant improved the most. It was observed in the second productions that the participant still uses present tenses instead of the past when recounting past events, especially when regular verbs are used. This is in line with the study about the universal order of morpheme acquisition carried out by Dulay, Burt, and Krashen (1982) where it was found that the irregular verbs were more promptly absorbed by learners.

Cohesion is another aspect that shows lack of improvement, especially in the appropriate use of connectors, which is recognized as one of the common problems faced by L2 learners (Chen, 2008). In this study a limited use of connectors was found in the second productions of the texts. It is possible that the participant avoided using connectors because she did not know how to use them appropriately.

Additionally, pronouns to substitute information were used the most. Production did not show lexical variety. There is a tendency to repeat the same words along the text (Ong, 2011). All these results agree with what was found in other studies (De Haan, \& van Esch 2008; Ong, 2011) where conjunctions and lexical cohesion are found to be the aspects which show more difficulties to manage appropriately.

The implementation of genre-based approach with mobile learning in the study helped the participant to feel interested and motivated in checking the contents related to the types of texts in the mobile device frequently. In other words, the participant showed a positive attitude towards writing activities. This is coherent with the experts, Emilia, Hermawan \& Nurhayati (2008) where they concluded that genre approach could empower students personally and cognitively. In general terms, university students have found in those devices the perfect allies to carry out academic activities (Al-Mukhaini, AlQayoudhi, \& Al-Badi, 2014; Olufadi, 2015). 


\section{CONCLUSIONS AND SUGGESTIONS}

This study implies that the use of mobile technology could be incorporated into a traditional English class, specifically the use of genre approach to work with writing skills. The analysis of the texts produced by the student showed an improved use of the language as well as some progress in the organization of the stages of the genre structure.

These results reveal that the genre approach to increase writing abilities with the support of mobile technology might generate positive results because the participant optimized the quality of the texts she produced in a short period of time. The explicit instruction of the aim of each stage of the types of texts by the teacher plus the support of podcasts where there was also an explanation helped the student to be more aware of how the different stages of text work.

The use of podcasts could also contribute to making students become the main actors of their own learning as they are encouraged to become independent and motivated students who are able to regulate their own learning pace and identify their weaknesses.

\section{REFERENCES}

Al-Mukhaini, E. M., Al-Qayoudhi, W. S., \& Al-Badi, A. H. (2014). Adoption of social networking in education: A study of the use of social networks by higher education students in Oman. Journal of International Education Research, 10(2), 143.

Chaisiri, T. (2010). Implementing a genre pedagogy to the teaching of writing in a university context in Thailand. Language Education in Asia, 1(1), 181-199.

Chen, J. (2008). An investigation of EFL students' use of cohesive devices. Asia Pacific Education Review, 5(2), 215-225.

Christie, F. (1987). Genres as choice. In I. Reid (Ed.), The place of genre in learning: Current debates (pp. 22-33). Geelong: Centre for Studies in Literacy Education, Deakin University (Typereader Publications 1)

Colombi, C. (2009). A Systemic Functional Approach to teaching Spanish for heritage speakers in the United States. Linguistics and Education, 20(1), $39-49$. 
De Haan, P., \& van Esch, K. (2008). Measuring and assessing the development of foreign language writing competence. Porta Linguarum: revista internacional de didáctica de las lenguas extranjeras, 9, 7-22.

Derewianka, B. (1990). Exploring how texts work. Rozelle, NSW: Primary English Teaching Association.

Dulay, H., Burt, M. K, \& Krashen, S. D.(1982). Language Two. New York: Oxford University Press.

Eggins, S. (2004). Introduction to systemic functional linguistics. New York: Continuum International Publishing Group.

Emilia, E., Hermawan, B., \& Nurhayati, D. T. (2008). A genre-based approach and the 2006 curriculum of English: Action research in a state junior high school in Bandung, West Java, Indonesia. A research report, submitted to the English Department, Indonesia University of Education.

Feez, S. (2002). Text-based syllabus design. Sydney: National Centre for English Language Teaching and Research, Macquarie University.

Ghio, E., \& Fernández, M.D. (2005). Manual de lingüistica sistémico funcional. El enfoque de M. A. K. Halliday and R. Hasan. Aplicaciones a la lengua española [Manual of systemic functional linguistics. The focus of M. A. K. Halliday and R. Hasan. Applications to the Spanish language]. Santa Fé, Argentina: Universidad Nacional del Litoral, Ediciones UNL.

Halliday, M. A. K., \& Hasan, R. (1976). Cohesion in English. London: Longman.

Hanson-Smith, E. (Ed.). (2000). Technologically enhanced learning environments. Alexandria, VA: Teachers of English to Speakers of Other Languages.

Hyland, K. (2007). Genre pedagogy: Language, literacy and L2 writing instruction. Journal of Second Language Writing, 16(3), 148-164.

Lirola, M. M. (2006). The importance of teaching systemic functional linguistics and text linguistics to improve writing in bilingual education programs in the USA. Porta Linguarum, 5, 139-150. 
Lirola, M. M., \& Cuevas, M. T. (2008). Integrating CALL and Genre Theory: A proposal to increase students' literacy. RECALL, 20(1), 67-81.

Looi, C., Seow, P., Zhang, B., So, H., Chen, W., \& Wong, L. (2010). Leveraging mobile technology for sustainable seamless learning: A research agenda. British Journal of Educational Technology, 41(2), 154169.

McCarthy, S. (2005). Spoken internet to go: Popularization through podcasting. JALT CALL Journal, 1(2), 67-74.

Martin, J. R. (1985). Factual writing: Exploring and challenging social reality. Geelong: Deakin University.

Martin, J. R. (1992). English text: System and structure. Amsterdam: John Benjamins.

Martin, F., \& Ertzberger, J. (2013). Here and now mobile learning: An experimental study on the use of mobile technology. Computers \& Education, 68, 76-85.

Martin, J. R., \& Rose, D. (2008). Genre relations: Mapping culture. London: Equinox.

Naish, R. (2005). Youth engaged by M-learning. E-learning Age, 2, 16-17.

Nunan, D. (1999). Second Language Teaching and Learning. Boston: Heinle \& Heinle.

O'Connell, M., \& Smith, J. (2007). A guide to working with m-learning standards: A manual for teachers, trainers and developers. Australian Government: Department of Education Science and Training.

Olufadi, Y. (2015). A configurational approach to the investigation of the multiple paths to success of students through mobile phone use behaviors. Computers \& Education, 86, 84-104.

Ong, J. (2011). Investigating the use of cohesive devices by Chinese EFL learners. Asian EFL Journal, 13(3), 42-65.

Rose, D. (2008). Reading to learn: Accelerating learning and closing the gap. Sydney: Reading to Learn. 
Sampieri, R. H., \& Mendoza, C. P. (2008). El matrimonio cuantitativocualitativo: el paradigma mixto [The quantitative and qualitative marriage]. In J. L. Álvarez Gayou (President), 6th Congress of research on sexology. Congress done by the Instituto Mexicano de Sexología, C. A. and the Universidad Juárez Autónoma de Tabasco, Villahermosa, Tabasco, Mexico.

Schleppegrell, M. J. (2006). The linguistic features of advanced language use: The grammar of exposition. In H. Byrnes (Ed.), Advanced language learning: The contribution of Halliday and Vygotsky (pp. 134-146). London: Continuum.

Shaughnessy, J., Zechmeister, E., \& Zechmeister, J. (2007). Métodos de investigación en psicología [Research methods in psychology] $\left(7^{a}\right.$ ed.). México D.F.: McGraw-Hill.

Stockwell, G. (2010). Using mobile phones for vocabulary activities: examining the effect of the platform. Language Learning and Technology, 14(2), 95-110.

Tangpermpoon, T. (2008). Integrating approaches to improve students writing skills for English major students. ABAC Journal, 28(2), 1-9.

Tardy, C. M. (Ed.) (2011). The history and future of genre in second language writing. Journal of Second Language Writing, 20(1), 1-5.

Taylor, J. (2007). Learning on the fly: Choose the right tools to deliver learning content to employees anytime, anywhere. HR Technology Magazine, pp. 127-131.

Tribble, C. (1996). Writing. Oxford: Oxford University Press.

Venkatesh, B., Nargundkar, R., Sayed, F., \& Shahaida, P. (2006). Assessing Indian students' perceptions towards m-learning. Some initial conclusions. International Journal of Mobile Marketing, 1(2), 75-79. 